\title{
Elevated sodium-lithium countertransport activity in erythrocytes is predictive of the development of microalbuminuria in IDDM
}

\author{
C.G . Monciotti ${ }^{1}$, A . Semplicini ${ }^{3}$, A . Morocutti ${ }^{2}$, M. Maioli ${ }^{5}$, M . R . Cipollina ${ }^{4}$, I. B arzon ${ }^{2}$, C. Palaro ${ }^{1}$, E . B rocco ${ }^{1}$, \\ M. Trevisan' ${ }^{2}$, P. Fioretto ${ }^{2}$, G . Crepaldi ${ }^{2}$, R . N osadini ${ }^{2,5}$ \\ ${ }^{1}$ Department of Paediatrics, University of Padova, Padova, Italy \\ ${ }^{2}$ Department of Internal Medicine and the National Research Center for the Study of Aging, University of Padova, Padova, Italy \\ ${ }^{3}$ Department of Clinical and Experimental Medicine, University of Padova, Padova, Italy \\ ${ }^{4}$ Diabetic Clinic, Ospedale Civile di Camposampiero, Padova, Italy \\ ${ }^{5}$ Diabetic Clinic and Department of Internal Medicine, University of Sassari, Sassari, Italy
}

Summary Pathogenetic mechanisms other than the quality of metabolic control may play a role in the development of diabetic nephropathy. Some cross-sectional studies have shown that elevated erythrocyte sodium-lithium countertransport $\left(\mathrm{Na}^{+} / \mathrm{Li}^{+} \mathrm{CT}\right)$ activity may be linked to incipient or overt nephropathy in insulin-dependent diabetic (IDDM) patients. The aim of the present work was to ascertain if high erythrocyte $\mathrm{Na}^{+} / \mathrm{Li}^{+} \mathrm{CT}$ activity anticipates the development of microalbuminuria in IDDM patients. Evaluation of this cation transport system was carried out in 159 normotensive, normoalbuminuric IDDM patients, who were divided into two groups: those with values above (Group A) and those with values below (Group B) the median level in the overall population $(300 \mu \mathrm{mol} /$ erythrocytes $\times \mathrm{h})$. A total of 79 patients in Group A and 80 in Group B underwent periodic examinations over a similar time period (5.2 years, range 3.3-7.4 years and 5.4 years, range 3.4-7.5 years, respectively). Median sodium-lithium countertransport activity was stable when evaluated after 2 and 4 years of follow-up. Only seven patients were excluded from the protocol because changes in their sodium-lithium countertransport activity placed them on the other side of the median value with respect to their baseline measurement. Thus, 152 patients completed the study (76 in Group A and 76 in Group B). Of the 76 patients in Group A, 17 developed persistent microalbuminuria $(22.3 \%)$. The number of patients in Group B showing persistent microalbuminuria was significantly lower (4 of $76 ; 5.2 \%$; $\mathrm{p}<0.01)$. The sensitivity of erythrocyte $\mathrm{Na}^{+} / \mathrm{Li}^{+} \mathrm{CT}$ in predicting the development of microalbuminuria was $85 \%$ and its specificity was $55 \%$. Seven patients of Group A and five of Group B developed arterial hypertension. Subjects in Group A had significantly higher mean $\mathrm{HbA}_{1 \mathrm{c}}$ values of twice yearly measurements than those in Group B $(9.6 \pm 1.7$ vs $8.3 \pm 1.7 \%, p<0.002$, mean $\pm \mathrm{SD})$ despite similar daily insulin requirements. Systolic and diastolic blood pressure levels were also evaluated every 6 months and were significantly higher in the Group A than in the Group B patients, although on average within the normal range. The odds ratio for developing persistent microalbuminuria in IDDM with elevated baseline erythrocyte $\mathrm{Na}^{+} / \mathrm{Li}^{+}$CT activity after adjustment for gender and baseline albumin excretion rate, and mean 6 monthly plasma creatinine, $\mathrm{HbA}_{1 \mathrm{c}}$ and systolic and diastolic blood pressure levels was $4.2(95 \%$ confidence intervals $2.0-11.1)$. It was also found that the percentage of offspring having both parents with $\mathrm{Na}^{+} / \mathrm{Li}^{+}$CTactivity above the median value was significantly higher in Group A than in Group B (Group A vs Group B: 35 vs 19\%; $p<0.01)$. On the contrary the percentage of offspring whose erythrocyte $\mathrm{Na}^{+} / \mathrm{Li}^{+} \mathrm{CT}$ was lower in both parents was lower in Group A than in Group B: 10 vs $38 \%, p<0.01)$. Parents of Group A offspring had arterial hypertension more frequently than those of Group B. These results indicate that erythrocyte $\mathrm{Na}^{+} / \mathrm{Li}^{+}$CT activity is a useful diagnostic tool in identifying normotensive, normoalbuminuric

Received: 10 September 1996 and in final revised form: 20 February 1997

Corresponding author: Dr. R. Nosadini, Istituto di Medicina Interna, Policlinico, Via Giustiniani 2, 35128 Padova, Italy

A bbreviations: IDDM, Insulin-dependent diabetes mellitus; AER, albumin excretion rate; $\mathrm{Na}^{+} / \mathrm{Li}^{+} \mathrm{CT}$, sodium-lithium countertransport activity; ANOVA, analysis of variance. 
patients who may be predisposed to develop persistent microalbuminuria. This disorder in the cation transport system is associated with poor metabolic control, higher blood pressure, and male sex; it also appears to be, at least partly, genetically transmitted. [Diabetologia (1997) 40: 654-661]
Keywords Diabetic nephropathy, erythrocyte sodium-lithium countertransport activity, hypertension.
The Diabetes Control and Complications Trial (DCCT) [1] clearly showed that poor glycaemic control plays a primary role in determining the development of renal damage in insulin-dependent diabetes mellitus (IDDM). More recently, a threshold value of glycated haemoglobin $\mathrm{A}_{1 \mathrm{c}}\left(\mathrm{HbA}_{1 \mathrm{c}}\right)$ has been identified. It was found that when $\mathrm{HbA}_{1 \mathrm{c}}$ is above $8.1 \%$, the risk of developing diabetic nephropathy increases sharply [2]. However, it has to be stressed that in the DCCT, although strict glycaemic control nearly halved the cumulative incidence rate of microalbuminuria during a 9-year follow-up, approximately $15 \%$ of IDDM patients still developed renal complications, despite good metabolic control.

Thus, other factors appear to play an important role in the pathogenesis of diabetic nephropathy in IDDM. The development of overt proteinuria in the first 20 years of IDDM is closely correlated to the predisposition to essential hypertension [3]. Moreover, the occurrence of microalbuminuria in the first 20 years of IDDM is likewise related to three indices of predisposition to essential hypertension: family history of hypertension, adolescent blood pressure and eythrocyte sodium-lithium countertransport activity $\left(\mathrm{Na}^{+} / \mathrm{Li}^{+} \mathrm{CT}\right)[4]$. Two cross-sectional studies reported that elevated erythrocyte $\mathrm{Na}^{+} / \mathrm{Li}^{+} \mathrm{CT}$ is associated with overt or incipent nephropathy in IDDM $[3,5]$. These findings, however, have not been confirmed by other authors [6]. Moreover, no information is available on the importance of elevated erythrocyte $\mathrm{Na}^{+} / \mathrm{Li}^{+}$CT in predicting micro- or macroalbuminuria in IDDM during prospective followup intervals.

The aim of the present study was to evaluate the role of erythrocyte $\mathrm{Na}^{+} / \mathrm{Li}^{+} \mathrm{CT}$ as a risk factor for the development of microalbuminuria in normotensive, normoalbuminuric IDDM patients.

\section{Subjects and methods}

We recruited 171 consecutive IDDM patients attending the outpatient clinics of the Department of Internal Medicine and of the Department of Paediatrics of the University of Padova and the District Hospital of Camposampiero (Padova) between 1 October 1987 and 1 December 1992. All of them were asked to participate in a screening programme for urinary albumin excretion rate (AER) and erythrocyte $\mathrm{Na}^{+} / \mathrm{Li}^{+} \mathrm{CT}$. The selection criteria were the following: onset of diabetes before the age of 30 years, insulin treatment within the first
3 months of diagnosis, sitting blood pressure below 140/ $90 \mathrm{mmHg}$ [7], no antihypertensive therapy or clinical or biochemical evidence of renal diseases, serum creatinine less than $106 \mu \mathrm{mol} / \mathrm{l}$, AER below $12 \mu \mathrm{g} / \mathrm{min}$ (mean \pm 2 SD in normal control subjects in our laboratory) as median value of three daily timed urine specimens.

The 159 patients who met these requirements gave informed consent to participate in a longitudinal study whose protocol was reviewed and approved by the ethical committees of the University of Padova and of the District Hospital, whereas 12 patients did not agree to adhere to the protocol study.

Erythrocyte $\mathrm{Na}^{+} / \mathrm{Li}^{+} \mathrm{CT}$ were measured in fasting venous blood specimens following methods described elsewhere [8, 9]. In the population of IDDM offspring erythrocyte $\mathrm{Na}^{+}$/ $\mathrm{Li}^{+} \mathrm{CT}$ was not significantly different between males and females $(311 \pm 135 \mu \mathrm{mol} / \mathrm{l}$ of erythrocyte per hour in males, $287 \pm 154$ in females, mean \pm SD, NS) and was not related to gender and age (r:0.04 and 0.02, NS, respectively). However, erythrocyte $\mathrm{Na}^{+} / \mathrm{Li}^{+} \mathrm{CT}$ was significantly related to gender in the parents of IDDM offspring $(r=0.39, p<0.05)$. Therefore, the IDDM offspring patients were divided into two groups on the basis of erythrocyte $\mathrm{Na}^{+} / \mathrm{Li}^{+}$CT without matching for gender. Group A had values above and Group B levels below the median value, e.g. $300 \mu \mathrm{mol} \cdot 1$ erythrocytes ${ }^{-1} \cdot \mathrm{h}^{-1}$ in the overall population. We also calculated the sensitivity positive, predicting value for the occurrence rate of microalbuminuria and the specificity negative, predicting value for the occurrence rate of microalbuminuria by adopting different cut-off points for erythrocyte $\mathrm{Na}^{+} / \mathrm{Li}^{+} \mathrm{CT}$ values as described in detail elsewhere [10].

All subjects were weighed in indoor clothing without shoes, and height was also recorded. Blood pressure was measured (phases I and V) twice on the right arm to the nearest $2 \mathrm{mmHg}$ using a Hawksley Random zero sphygmomanometer by two different authors of the present study (R.N. and G.M.). Measurement was made with subjects in a supine position after 10 min rest. Mean arterial pressure was calculated as the diastolic pressure plus one-third of the pulse pressure and the mean of the two measurements used for calculation. All patients were examined and blood was collected in the morning after an overnight fast. Patients' morning insulin injections were deferred until after this procedure. The same procedures were used to evaluate the clinical and biochemical features of the parents of IDDM patients. More particularly, arterial hypertension was diagnosed, when sitting blood pressure level was above $140 / 90 \mathrm{mmHg}$ in untreated subjects or when the patients were taking antihypertensive therapy. This latter criterion was the case in the large majority of the parents.

All patients were prescribed a relatively low protein $(1.0 \mathrm{~g} /$ day), low salt (90 mEq $\cdot 1.73 \mathrm{~m}^{-2} \cdot$ day $\left.^{-1}\right)$, isocaloric (2000 kcal · $\left.1.73 \mathrm{~m}^{-2} \cdot \mathrm{day}^{-1}\right)$ diet, which closely resembles the nutritional habits of the control population in northeast Italy. Patients were examined at baseline and every 6 months when $\mathrm{HbA}_{1 \mathrm{c}}$, serum creatinine, plasma electrolytes, cholesterol, triglycerides, AER from three 24-h urine collections, body weight and 
arterial blood pressure were measured. Erythrocyte $\mathrm{Na}^{+} / \mathrm{Li}^{+}$ CT was measured at baseline and after 2- and 4-years of follow-up. $\mathrm{HbA}_{1 \mathrm{c}}$ was measured by high-liquid pressure chromatography [11] and serum creatinine, triglycerides, cholesterol, sodium and potassium by automatic analyser [12]. AER was measured by radioimmunoassay, as described elsewhere [13].

Persistent microalbuminuria was defined as an AER above $20 \mu \mathrm{g} / \mathrm{min}$ at all subsequent measurements (at least three values every 6 months) after the first assessment. Intermittent microalbuminuria was defined as an AER not constantly above $20 \mu \mathrm{g} / \mathrm{min}$ at subsequent measurements (at least three values every 6 months). We also evaluated the cumulative absolute change of AER ( $\mu \mathrm{g} / \mathrm{min})$ from baseline values during the 5.3year follow-up period.

\section{Statistical analysis}

Standard descriptive statistics were used to describe the distribution of variables between the two patient groups. Values are given as mean \pm SD or median with ranges. Comparisons between the values observed during the follow-up period in Group A and B offspring used a two-factor analysis of variance (ANOVA) with erythrocyte $\mathrm{Na}^{+} / \mathrm{Li}^{+} \mathrm{CT}$ category and time (baseline and follow-up period) as the factors, when a significant interaction was shown by ANOVA. For the sake of clearness, exposition data for the follow-up period are expressed as mean values of subsequent determinations every 6 months. Chi-square tests, two-tailed Student's t-test or Mann-Whitney non-parametric test were used to assess the degree of statistical significance of differences. These tests were also used to analyse baseline values of offspring and their parents. As the descriptive measure of association between risk factors and each of the outcomes, odds ratios have been given together with $95 \%$ confidence intervals [14]. These odds ratios were based on the cumulative incidence rates of micro-macroalbuminuria during the 5.3-year follow-up interval (the average in the two pooled groups). Multiple logistic regression analysis was used to study the relationship between the occurrence rate of microalbuminuria (dependent variable) and the baseline rate of activity of erythrocyte $\mathrm{Na}^{+} / \mathrm{Li}^{+} \mathrm{CT}$ (independent variable), while simultaneously controlling for gender and baseline $\mathrm{AER}$, and the mean values of plasma creatinine, $\mathrm{HbA}_{1 \mathrm{c}}$ and systolic and diastolic blood pressure levels every 6 months during the follow-up period. These independent variables were chosen because of their univariate associations with the occurrence rate of microalbuminuria. The occurrence rate of persistent microalbuminuria was treated as dichotomous (AER above vs AER below $20 \mu \mathrm{g} / \mathrm{min}$ ) and as continuous numerical variable (cumulative absolute change of AER ( $\mu \mathrm{g} / \mathrm{min})$ from baseline. Gender and erythrocyte $\mathrm{Na}^{+} / \mathrm{Li}^{+} \mathrm{CT}$ (above vs below the median value of $300 \mu \mathrm{mol} \cdot 1$ erythrocytes ${ }^{-1} \cdot \mathrm{h}^{-1}$ were treated as dichotomous variables. Statistical analysis was carried out using SPSS 6.1 Base System software (SPSS Inc., Chicago, Ill., USA).

\section{Results}

Sodium-lithium countertransport activity in IDDM offspring and parents. The median value of erythrocyte $\mathrm{Na}^{+} / \mathrm{Li}^{+}$CT in the IDDM patients who took part in the study (159 out of 171 interviewed patients) was $300 \mu \mathrm{mol} \cdot 1$ erythrocyte ${ }^{-1} \cdot \mathrm{h}^{-1}$. Eighty patients had values higher and 79 had lower than the median
Table 1. Erythrocyte $\mathrm{Na}^{+} / \mathrm{Li}^{+} \mathrm{CT} \mu \mathrm{mol} \cdot 1$ erythrocytes ${ }^{-1} \cdot \mathrm{h}^{-1}$ in IDDM patients at baseline and at year 2 and 4 of follow-up

\begin{tabular}{lllll}
\hline & Baseline & Year 2 & Year 4 & $\begin{array}{l}\text { Coefficient } \\
\text { of variation } \\
(\%)\end{array}$ \\
\hline Group A & $429 \pm 122$ & $430 \pm 113$ & $421 \pm 148$ & $11 \pm 9$ \\
& $(300-748)$ & $(303-759)$ & $(301-771)$ & \\
Group B & $188 \pm 104$ & $191 \pm 113$ & $184 \pm 96$ & $9 \pm 8$ \\
& $(104-299)$ & $(103-289)$ & $(101-296)$ & \\
\hline
\end{tabular}

Values are mean \pm SD and (range)

N.B. The patients were divided into two groups: A, those with values of erythrocyte $\mathrm{Na}^{+} / \mathrm{Li}^{+} \mathrm{CT}$ above, and $\mathrm{B}$, those with values below, the median level in the overall population $\left(300 \mu \mathrm{mol} \cdot 1\right.$ erythrocytes $\left.{ }^{-1} \cdot \mathrm{h}^{-1}\right)$

level and were assigned to Group A and Group B, respectively. Seven patients showed, after 2 or 4 years, alterations in erythrocyte $\mathrm{Na}^{+} / \mathrm{Li}^{+} \mathrm{CT}$ levels which placed them on the other side of the median value with respect to their baseline measurement. These were excluded from our protocol. Twelve patients developed arterial hypertension (systolic and/or diastolic blood pressure levels above $140 / 90 \mathrm{mmHg}$ ), and were prescribed antihypertensive medication, but were not excluded from the study. The present work thus considers data on 152 IDDM patients. No change in erythrocote $\mathrm{Na}^{+} / \mathrm{Li}^{+}$CT values was observed between baseline, 2 and 4 year measurements (Table 1). The two groups of IDDM patients were comparable for age, duration of diabetes, body mass index and biochemical parameters. In particular no differences were found with regard to baseline AER and $\mathrm{HbA}_{1 \mathrm{c}}$ levels. Systolic blood pressure levels were slightly but significantly higher in Group A than $\mathrm{B}$ patients, albeit within the normal range. No significant differences were observed with regard to diastolic blood pressure. The number of males was significantly higher in Group A than B (Table 2).

Erythrocyte $\mathrm{Na}^{+} / \mathrm{Li}^{+}$CT was measured in both parents of 61 out of 76 patients in Group A and 64 out of 76 patients in Group B. Their clinical features are shown in Table 3. The average age of the fathers was greater than that of the mothers in both groups. However, no difference was observed with regard to age between parents of Group A and B as overall cohorts of males and females. The number of subjects undergoing antihypertensive therapy was significantly higher in the parents of Group A than those of Group B (24 vs $11 \%$; $p<0.05)$. Mean blood pressure levels of the parents of Group A and Group B IDDM offspring, who were not taking antihypertensive therapy were similar. Blood pressure levels tended to be slightly higher in the fathers than in the mothers of offspring IDDM patients, as were triglyceride plasma concentrations (Table 3 ).

Erythrocyte $\mathrm{Na}^{+} / \mathrm{Li}^{+} \mathrm{CT}$ was greater in males than females among parents of IDDM offspring. 
Table 2. Baseline clinical features of the IDDM patients who completed the study

\begin{tabular}{|c|c|c|c|}
\hline & Group A & Group B & $P$-value \\
\hline Sex (Male/female) & $48 / 28$ & $38 / 38$ & $p<0.01$ \\
\hline Age (years) & $17.3 \pm 7.4$ & $18.4 \pm 6.2$ & NS \\
\hline $\begin{array}{l}\text { Duration of IDDM } \\
\text { (years) }\end{array}$ & $5.8 \pm 4.2$ & $6.4 \pm 3.9$ & NS \\
\hline $\begin{array}{ll}\text { Blood pressure } & \text { Systolic } \\
(\mathrm{mm} \mathrm{Hg}) & \text { Diastolic }\end{array}$ & $\begin{array}{l}123 \pm 17 \\
75 \pm 8\end{array}$ & $\begin{array}{l}118 \pm 17 \\
74 \pm 16\end{array}$ & $\begin{array}{l}\mathrm{p}<0.05 \\
\mathrm{NS}\end{array}$ \\
\hline $\mathrm{HbA}_{1 \mathrm{c}}(\%)$ & $8.9 \pm 2.6$ & $8.6 \pm 3.4$ & NS \\
\hline Cholesterol (mmol/1) & $4.1 \pm 1.7$ & $4.2 \pm 0.8$ & NS \\
\hline Triglycerides (mmol/l) & $0.99 \pm 1.13$ & $1.03 \pm 0.95$ & NS \\
\hline Plasma creatinine $(\mu \mathrm{mol} / \mathrm{l})$ & $70 \pm 17$ & $69 \pm 24$ & NS \\
\hline $\begin{array}{l}\text { Creatinine clearance } \\
\left(\mathrm{ml} \cdot \min 1.73^{-1} \cdot \mathrm{m}^{-2}\right)\end{array}$ & $117 \pm 104$ & $109 \pm 104$ & NS \\
\hline $\begin{array}{l}\text { Insulin requirement } \\
\left(\mathrm{IU} \cdot \mathrm{day}^{-1} \cdot \mathrm{kg}^{-1}\right)\end{array}$ & $0.88 \pm 0.60$ & $0.77 \pm 0.78$ & NS \\
\hline $\begin{array}{l}\text { Background/proliferative } \\
\text { retinopathy }(\%)\end{array}$ & $29 / 0$ & $26 / 0$ & NS \\
\hline $\begin{array}{l}\text { Albumin excretion rate } \\
(\mu \mathrm{g} / \mathrm{min})\end{array}$ & $8(1-10)$ & $7(2-9)$ & NS \\
\hline
\end{tabular}

Each clinical and biochemical parameter represents the mean of a single evaluation in the IDDM offspring

N. B. Group A had levels above and Group B levels below the median value erythrocyte $\mathrm{Na}^{+} / \mathrm{Li}^{+} \mathrm{CT}(300 \mu \mathrm{mol} \cdot 1$ erythrocytes $\left.^{-1} \cdot h^{-1}\right)$. Mean \pm SD or median with ranges at baseline

However, parents of Group A patients had higher erythrocyte $\mathrm{Na}^{+} / \mathrm{Li}^{+}$CT values on average than did those of Group B (fathers: 356 vs 266, p < 0.05; mothers: 277 vs $221, \mu \mathrm{mol} \cdot 1$ erythrocyte $\left.{ }^{-1} \cdot \mathrm{h}^{-1}, \mathrm{p}<0.01\right)$. The number of IDDM patients in Group A whose erythrocyte $\mathrm{Na}^{+} / \mathrm{Li}^{+}$CT was greater in both parents than the median value in the parent population (e.g. 277), was significantly higher than that in Group B (35 vs $19 \%$ ). On the contrary, the number of IDDM patients in Group A whose erythrocyte $\mathrm{Na}^{+} / \mathrm{Li}^{+} \mathrm{CT}$ was lower in both parents than the median value was significantly lower than that in Group B (10 vs $38 \%$ ) (chi-square: $p<0.01$ ). No difference was found between the two groups with respect to the number of IDDM patients who had only one parent with erythrocyte $\mathrm{Na}^{+} / \mathrm{Li}^{+} \mathrm{CT}$ greater than the median value (55 vs $43 \%$, NS).
Table 4. Mean clinical features of IDDM patients who completed the study

\begin{tabular}{|c|c|c|c|c|}
\hline \multirow{2}{*}{$\begin{array}{l}\text { Blood pressure } \\
(\mathrm{mm} \mathrm{Hg})\end{array}$} & & Group A & Group B & $P$-value \\
\hline & $\begin{array}{l}\text { Systolic } \\
\text { Diastolic }\end{array}$ & $\begin{array}{l}124 \pm 17 \\
77 \pm 9\end{array}$ & $\begin{array}{l}117 \pm 17 \\
73 \pm 8\end{array}$ & $\begin{array}{l}p<0.05 \\
p<0.01\end{array}$ \\
\hline \multicolumn{2}{|l|}{$\mathrm{HbA}_{1 \mathrm{c}}(\%)$} & $9.6 \pm 1.7$ & $8.3 \pm 1.7$ & $p<0.002$ \\
\hline \multicolumn{2}{|c|}{ Cholesterol (mmol/l) } & $4.4 \pm 0.19$ & $4.6 \pm 0.8$ & NS \\
\hline \multicolumn{2}{|c|}{ Triglycerides (mmol/l) } & $1.02 \pm 1.39$ & $1.00 \pm 0.95$ & NS \\
\hline \multicolumn{2}{|c|}{ Plasma creatinine $(\mu \mathrm{mol} / \mathrm{l})$} & $78 \pm 17$ & $74 \pm 24$ & NS \\
\hline \multicolumn{2}{|c|}{$\begin{array}{l}\text { Creatinine clearance } \\
\left(\mathrm{ml} \cdot \min 1.73^{-1} \cdot \mathrm{m}^{-2}\right)\end{array}$} & $107 \pm 87$ & $115 \pm 95$ & NS \\
\hline \multicolumn{2}{|c|}{$\begin{array}{l}\text { Insulin requirement } \\
\left(\mathrm{IU} \cdot \mathrm{day}^{-1} \cdot \mathrm{kg}^{-1}\right)\end{array}$} & $0.92 \pm 0.69$ & $0.74 \pm 0.34$ & NS \\
\hline \multicolumn{2}{|c|}{$\begin{array}{l}\text { Background/proliferative } \\
\text { retinopathy }(\%)\end{array}$} & $47 / 4$ & $36 / 1$ & $p<0.05$ \\
\hline
\end{tabular}

Each value (except for eye evaluation) represents the average of subsequent determinations every 6 months during the follow-up period

N.B. Group A had levels above and Group B levels below the median value erythrocyte $\mathrm{Na}^{+} / \mathrm{Li}^{+} \mathrm{CT}(300 \mu \mathrm{mol} \cdot 1$ erythrocytes $^{-1} \cdot \mathrm{h}^{-1}$ ) expressed as mean values of the measurements performed every 6 months during the follow-up period

Rate of development of microalbuminuria in IDDM offspring. During the follow-up period Group A patients had significantly higher mean $\mathrm{HbA}_{1 \mathrm{c}}$ values than did Group B (Table 4) despite similar daily insulin requirements. Systolic and diastolic blood pressure levels were slightly, but significantly, higher in Group A than in Group B, although within the normal range (Table 4). No differences were observed with regard to other clinical and biochemical parameters. The number of patients who developed persistent microalbuminuria during the follow-up period in the overall population of normotensive and hypertensive IDDM offspring population was significantly higher in Group A than in Group B (Table 5). No significant differences were observed with regard to the rate of development of intermittent microalbuminuria (Table 5). Twelve patients developed arterial hypertension, seven in Group A and five in Group B. The rate of occurrence of microalbuminuria was also assessed excluding these patients because of the possibility that antihypertensive treatment affects AER.

Table 3. Clinical features of the parents of IDDM offspring

\begin{tabular}{|c|c|c|c|c|c|c|c|c|c|}
\hline & & $\begin{array}{l}\text { Age } \\
\text { (years) }\end{array}$ & $\begin{array}{l}\text { Body mass } \\
\text { index } \\
\left(\mathrm{kg} / \mathrm{m}^{2}\right)\end{array}$ & $\begin{array}{l}\text { Blood } \\
\text { glucose } \\
(\mathrm{mmol} / \mathrm{l})\end{array}$ & $\begin{array}{l}\text { Triglyce- } \\
\text { rides } \\
(\mathrm{mmol} / \mathrm{l})\end{array}$ & $\begin{array}{l}\text { Cholesterol } \\
(\mathrm{mmol} / \mathrm{l})\end{array}$ & $\begin{array}{l}\text { Mean blood } \\
\text { pressure } \\
(\mathrm{mm} \mathrm{Hg})\end{array}$ & $\begin{array}{l}\text { Hyper- } \\
\text { tension } \\
(\%)\end{array}$ & $\begin{array}{l}\text { IDDM } \\
(\%)\end{array}$ \\
\hline $\begin{array}{l}\text { Parents of Group A } \\
(n=61)\end{array}$ & $\begin{array}{l}\text { Female } \\
\text { Male }\end{array}$ & $\begin{array}{l}46 \pm 8^{b} \\
44 \pm 8\end{array}$ & $\begin{array}{l}24 \pm 7 \\
25 \pm 8\end{array}$ & $\begin{array}{l}4.72 \pm 1.61 \\
4.38 \pm 0.86\end{array}$ & $\begin{array}{l}1.34 \pm 0.78 \\
0.98 \pm 0.70\end{array}$ & $\begin{array}{l}4.24 \pm 0.54 \\
4.11 \pm 0.86\end{array}$ & $\begin{array}{l}107 \pm 12 \\
101 \pm 13\end{array}$ & $\begin{array}{l}28^{\mathrm{a}} \\
20^{\mathrm{a}}\end{array}$ & $\begin{array}{l}0 \\
0\end{array}$ \\
\hline $\begin{array}{l}\text { Parents of Group B } \\
(n=64)\end{array}$ & $\begin{array}{l}\text { Female } \\
\text { Male }\end{array}$ & $\begin{array}{l}44 \pm 8^{b} \\
40 \pm 16\end{array}$ & $\begin{array}{l}25 \pm 8 \\
23 \pm 8\end{array}$ & $\begin{array}{l}4.62 \pm 1.12 \\
4.20 \pm 1.04\end{array}$ & $\begin{array}{l}1.21 \pm 0.88 \\
0.97 \pm 0.88\end{array}$ & $\begin{array}{l}4.18 \pm 0.72 \\
4.07 \pm 0.96\end{array}$ & $\begin{aligned} 102 & \pm 6 \\
98 & \pm 13\end{aligned}$ & $\begin{array}{r}14 \\
7\end{array}$ & $\begin{array}{l}0 \\
0\end{array}$ \\
\hline
\end{tabular}

Presence of arterial hypertension and IDDM is expressed as percentage. Mean blood pressure levels were measured only in subjects not receiving antihypertensive treatment.

${ }^{a} p<0.05$ parents of Group A vs parents of Group B; ${ }^{b} p<0.05$ males vs females 
Table 5. Development of persistent or intermittent microalbuminuria in each of the two groups

\begin{tabular}{llll}
\hline & Group A & Group B & P -value \\
\hline $\begin{array}{l}\text { Duration of follow-up } \\
\text { (years) }\end{array}$ & $\begin{array}{l}5.2 \\
(3.3-7.4)\end{array}$ & $\begin{array}{l}5.4 \\
(3.5-7.5)\end{array}$ & $\mathrm{NS}$ \\
$\begin{array}{l}\text { Persistent microalbu- } \\
\text { minuria in normotensive } \\
\text { offspring }\end{array}$ & $\begin{array}{l}14 \text { of } 69 \\
(20.2 \%)\end{array}$ & $\begin{array}{l}4 \text { of } 71 \\
(5.6 \%)\end{array}$ & $\mathrm{p}<0.01$ \\
$\begin{array}{l}\text { Persistent microalbu- } \\
\text { minuria in all offspring }\end{array}$ & $\begin{array}{l}17 \text { of } 76 \\
(22.3 \%)\end{array}$ & $\begin{array}{l}4 \text { of } 76 \\
(5.2 \%)\end{array}$ & $\mathrm{p}<0.01$ \\
$\begin{array}{l}\text { Intermittent microalbu- } \\
\text { minuria in all offspring }\end{array}$ & $\begin{array}{l}2 \text { of } 76 \\
(2.6 \%)\end{array}$ & $\begin{array}{l}2 \text { of } 76 \\
(2.6 \%)\end{array}$ & $\mathrm{NS}$ \\
\hline
\end{tabular}

Data are mean and range of follow-up period and number of patients

N. B. Group A had levels above and Group B levels below the median value erythrocyte $\mathrm{Na}^{+} / \mathrm{Li}^{+}$CT $(300 \mu \mathrm{mol} \cdot 1$ erythrocytes $\left.^{-1} \cdot \mathrm{h}^{-1}\right)$

Table 6. Operative characteristics of erythrocyte $\mathrm{Na}^{+} / \mathrm{Li}^{+} \mathrm{CT}$ as predicting factor of the rate of occurrence of microalbuminuria in the overall IDDM population during the follow-up period

\begin{tabular}{|c|c|c|}
\hline $\begin{array}{l}\text { Cut-off value } \\
\left(\mu \mathrm{mol} \cdot 1 \text { erythrocytes }{ }^{-1} \cdot \mathrm{h}^{-1}\right)\end{array}$ & $\begin{array}{l}\text { Sensitivity } \\
(\%)\end{array}$ & $\begin{array}{l}\text { Specificity } \\
(\%)\end{array}$ \\
\hline 0.20 & 90 & 27 \\
\hline 0.30 & 85 & 55 \\
\hline 0.40 & 70 & 88 \\
\hline 0.50 & 55 & 96 \\
\hline
\end{tabular}

Sensitivity indicates the true positive rate of development of microalbuminuria for a given cut off value;

Specificity indicates the true negative rate of development of microalbuminuria for a given cut-off value

Table 7. Results of multiple logistic regression analysis

\begin{tabular}{lll}
\hline Variable & Odds ratio $^{\mathrm{a}}$ & $\begin{array}{l}95 \% \text { Confidence } \\
\text { interval }\end{array}$ \\
\left.\hline${\text { Erythrocyte } \mathrm{Na}^{+} / \mathrm{Li}^{+} \mathrm{CT}(0 \text { or } 1)}\right)$ & $4.2^{\mathrm{b}}$ & $2.0-11.1$ \\
$\mathrm{HbA}_{1 \mathrm{c}}(\%)$ & $1.6^{\mathrm{c}}$ & $0.7-2.3$ \\
Triglycerides $(\mathrm{mmol} / \mathrm{l})$ & $0.9^{\mathrm{c}}$ & $0.4-1.0$ \\
Systolic blood pressure $(\mathrm{mm} \mathrm{Hg})$ & $1.3^{\mathrm{c}}$ & $0.7-1.1$ \\
Diastolic blood pressure $(\mathrm{mm} \mathrm{Hg})$ & $1.4^{\mathrm{c}}$ & $0.8-1.2$ \\
Baseline AER $(\mu \mathrm{gg} / \mathrm{min})$ & $0.9^{\mathrm{c}}$ & $0.4-1.1$ \\
Gender $(0$ or 1$)$ & $2.0^{\mathrm{c}}$ & $0.9-3.1$ \\
Plasma creatinine $(\mu \mathrm{mol} / \mathrm{l})$ & $0.7^{\mathrm{c}}$ & $0.5-0.9$
\end{tabular}

$\mathrm{HbA}_{1 \mathrm{c}}$, systolic and diastolic blood pressure level, gender and erythrocyte $\mathrm{Na}^{+} / \mathrm{Li}^{+} \mathrm{CT}$ are the independent variables. Dependent variable: Rate of occurrence of microalbuminuria (expressed as dichotomous variable)

${ }^{a}$ Odds ratio concerning numerical and categorial values shown in parentheses. Apart from gender and baseline AER, the other variables indicate the mean value of sequential determinations every 6 months during the follow-up period.

${ }^{\mathrm{b}} \mathrm{p}<0.01 ;{ }^{\mathrm{c}} \mathrm{NS}$

However, the degree of significance in the rate of development of both persistent and intermittent microalbuminuria did not vary in the two groups even if the data on these hypertensive patients were included (Table 5).
Table 6 shows the sensitivity of different cut off values of erythrocyte $\mathrm{Na}^{+} / \mathrm{Li}^{+} \mathrm{CT}$ in predicting the rate of occurrence of microalbuminuria. The erythrocyte $\mathrm{Na}^{+} / \mathrm{Li}^{+}$CT value of $300 \mu \mathrm{mol} \cdot 1$ erythrocyte ${ }^{-1}$. $\mathrm{h}^{-1}$ identified 17 truly positive and 3 false negative patients, e.g. it had a sensitivity of $85 \%$. The erythrocyte $\mathrm{Na}^{+} / \mathrm{Li}^{+}$CT value of $400 \mu \mathrm{mol} \cdot 1$ erythrocyte ${ }^{-1}$. $\mathrm{h}^{-1}$, which has been previously used mainly in crosssectional studies, identified 14 truly positive and 6 false negative patients, e.g. it had a significantly lower sensitivity $(70 \%, p<0.05)$. The specificity, e.g. the number of false positive patients, was significantly lower using the 400 cut-off point (Table 6). However, sensitivity rather than specificity, is the most prominent clinical parameter in follow-up studies, focusing on diabetic complications.

The cumulative, absolute increase of AER above baseline values, during the 5.3-year follow-up period, was significantly greater in Group A than in Group B $(10.8 \pm 25.2$ vs $2.11 \pm 10.4 \mu \mathrm{g} / \mathrm{min}, \mathrm{p}<0.01)$. The increase of AER above baseline did not correlate with baseline AER, but was highly significantly related to the baseline erythrocyte $\mathrm{Na}^{+} / \mathrm{Li}^{+} \mathrm{CT}(\mathrm{p}<0.002)$ and to gender $(p<0.03)$ and slightly, but significantly, related to the mean values of $\mathrm{HbA}_{1 \mathrm{c}}$ during the follow-up period $(p<0.04)$. Neither systolic nor diastolic blood pressure levels were significantly related to the occurrence rate of microalbuminuria. At the end of the follow-up interval the percentage of patients with background and proliferative retinopathy was higher in Group A (Table 4).

Table 7 shows the odds ratios from the logistic analysis used to control for the covariates. The rate of development of microalbuminuria, as a dichotomous variable, was associated with baseline erythrocyte $\mathrm{Na}^{+} / \mathrm{Li}^{+}$CT after adjustment for baseline AER and gender and $\mathrm{HbA}_{1 \mathrm{c}}$, triglyceride and mean blood pressure levels, expressed as average values of the sequential determinations every 6 months in each subject during the follow-up $(p<0.002)$. The odds ratio for the occurrence of microalbuminuria after adjustment for the above-mentioned confounding variables in IDDM with elevated baseline erythrocyte $\mathrm{Na}^{+} /$ $\mathrm{Li}^{+}$CT was 4.2 (95\% confidence intervals of 2.0 11.1). Similar results were observed using the cumulative absolute increase of AER above baseline as the continuous numerical variable.

\section{Discussion}

The results of the present study indicate that the risk of developing persistent microalbuminuria is greater in normotensive, normoalbuminuric IDDM patients with elevated erythrocyte $\mathrm{Na}^{+} / \mathrm{Li}^{+} \mathrm{CT}$. This risk is more evident in male patients, in keeping with the observation that diabetic nephropathy is more frequently shown by male than female IDDM patients. 
Moreover, elevated patterns of erythrocyte $\mathrm{Na}^{+} / \mathrm{Li}^{+}$ CT are associated with poor glycaemic control, as suggested by higher $\mathrm{HbA}_{1 \mathrm{c}}$ levels. Finally, it was found that IDDM patients with elevated erythrocyte $\mathrm{Na}^{+} / \mathrm{Li}^{+}$CT have slightly, but constantly, higher blood pressure values.

The results of the current study on the rate of occurrence of microalbuminuria in IDDM are consistent with the findings of the Microalbuminuria Collaborative Study Group [15], carried out in the United Kingdom, which reported an incidence rate of $2 \%$ per year for persistent microalbuminuria and $17 \%$ for intermittent microalbuminuria in a cohort of 137 IDDM patients.

The physiological significance of erythrocyte $\mathrm{Na}^{+} / \mathrm{Li}^{+}$CT in vivo is not yet understood. It has been postulated that it reflects the activity of sodium/hydrogen exchange in vivo, e.g. the membrane cation transport system which reflects intracellular $\mathrm{pH}$, cell growth and bicarbonate reabsorption by proximal tubules in the kidney [16]. However, more recently evidence has been provided that the erythrocyte $\mathrm{Na}^{+} / \mathrm{Li}^{+} \mathrm{CT}$ system differs from that of several isoforms of sodium/hydrogen exchange in mammals [17]. Why this transport system is elevated in this group of IDDM patients is not entirely clear but the explanation can probably be attributed to inherited genetic, rather than to environmental, factors [18].

This view is supported by the finding that despite a $10 \%$ coefficient of variation of erythrocyte $\mathrm{Na}^{+} / \mathrm{Li}^{+} \mathrm{CT}$ activity which may have caused the misclassification of some patients, only 7 out of 159 patients $(4 \%)$ crossed over from A to B or vice versa. According to our findings, the activity of this cation appears to be stable over prolonged periods. Moreover, it has been found that parents of offspring with elevated erythrocyte $\mathrm{Na}^{+} / \mathrm{Li}^{+}$ $\mathrm{CT}$ also show significantly increased cation transport activities.

Erythrocyte $\mathrm{Na}^{+} / \mathrm{Li}^{+} \mathrm{CT}$ has different kinetic abnormalities regarding both apparent affinity for external sodium $\left(\mathrm{K}_{\mathrm{m}}\right)$ and maximal velocity of cation translocation $\left(\mathrm{V}_{\max }\right)[19,20]$. Both are abnormal in patients with essential hypertension $[19,20]$ and diabetic nephropathy [21]. Assessing erythrocyte $\mathrm{Na}^{+}$/ $\mathrm{Li}^{+} \mathrm{CT}$ at only one external sodium concentration $(150 \mathrm{mmol} / \mathrm{l})$ accurately estimates neither $K_{m}$ nor $\mathrm{V}_{\max }$. However, this method has been validated in many epidemiological studies (for review, see [22]) and it is definitely more practical and accurate for clinical use. Therefore, we have used this method to assess its value in the long-term prediction of the risk of developing microalbuminuria, as has already been done for assessing the risk of developing hypertension $[23,24]$.

A screening test has to be sensitive and not necessarily specific [10]. With the median value $(300 \mu \mathrm{mol}$ $\cdot 1$ cells $^{-1} \cdot \mathrm{h}^{-1}$ ) as a cutoff point, in the present study the sensitivity of erythrocyte $\mathrm{Na}^{+} / \mathrm{Li}^{+}$CT in predicting the development of microalbuminuria at a 5-year follow up is $85 \%$ and its specificity $55 \%$ (Table 5). As with other screening tests, using more stringent criteria or higher cutoff values increases the specificity but lowers the sensitivity [10]. For instance, by increasing the cutoff value to $400 \mu \mathrm{mol} \cdot 1 \mathrm{cell}^{-1} \cdot \mathrm{h}^{-1}$, the specificity increases to $88 \%$ but the sensitivity falls to $70 \%$. For this reason we chose a reasonably low cutoff value $\left(300 \mu \mathrm{mol} \cdot 1 \mathrm{cell}^{-1} \cdot \mathrm{h}^{-1}\right)$ for erythrocyte $\mathrm{Na}^{+} / \mathrm{Li}^{+}$CT which gives a low false-negative rate $(15 \%)$ and high negative predictive value $(96 \%)$. This means that when erythrocyte $\mathrm{Na}^{+} / \mathrm{Li}^{+}$ $\mathrm{CT}$ is higher than $300 \mu \mathrm{mol} \cdot 1 \mathrm{cell}^{-1} \cdot \mathrm{h}^{-1}$ the development of microalbuminuria in a 5-year follow up is not certain but when it is lower than $300 \mu \mathrm{mol} \cdot 1$ cell ${ }^{-1} \cdot \mathrm{h}^{-1}$ the probability of renal complications is very low.

Erythrocyte $\mathrm{Na}^{+} / \mathrm{Li}^{+} \mathrm{CT}$ has been shown to be a genetic marker indicating a predisposition to arterial hypertension in non-diabetic populations [8]. This is in keeping with our present findings showing a slight but constant elevation in blood pressure levels in Group A. Furthermore, this view is also supported by the observation that arterial hypertension was more frequently found among the parents of Group A than B offspring. It can be postulated that the haemodynamic challenge due to blood pressure levels in the normal-upper range, may contribute to determining microalbuminuria in IDDM patients, although this view has not been uniformly confirmed in the literature [6].

The significance of the association between increased erythrocyte $\mathrm{Na}^{+} / \mathrm{Li}^{+} \mathrm{CT}$ and raised $\mathrm{HbA}_{1 \mathrm{c}}$ levels in the Group A patients is unclear. Impaired insulin sensitivity is linked to increased erythrocyte $\mathrm{Na}^{+} / \mathrm{Li}^{+} \mathrm{CT}$ in insulin-dependent $[25,26]$ and noninsulin-dependent [27] diabetes and in essential hypertension [28]. Poor metabolic control could be explained by resistance to insulin action in patients with elevated erythrocyte $\mathrm{Na}^{+} / \mathrm{Li}^{+}$CT. Patterns of $\mathrm{HbA}_{1 \mathrm{c}}$ levels constantly above $8.1 \%$ found in Group A patients could themselves lead to renal damage. In fact, it has recently been shown that the risk of developing nephropathy increases logarithmically when $\mathrm{HbA}_{1 \mathrm{c}}$ is above the threshold value of $8.1 \%$ in IDDM patients with [2]. Although more recently the DCCT data do not support the conjecture that a glycaemic threshold for the development of complications exists at an $\mathrm{HbA}_{1 \mathrm{c}}$ of $8 \%$, this latter report still confirms the role of hyperglycaemia in the pathogenesis of renal and retinal damage in IDDM [29].

With regard to the relation between erythrocyte $\mathrm{Na}^{+} / \mathrm{Li}^{+} \mathrm{CT}$ and gender the present study shows that the fathers of IDDM offspring had higher activities than the mothers. These findings are 
consistent with previous reports that erythrocyte $\mathrm{Na}^{+} / \mathrm{Li}^{+} \mathrm{CT}$ is higher in males than females [22]. However, this was not true among IDDM offspring. Although the reason for this observation deserves further investigation, it can be postulated that uniformly elevated circulating insulin levels conceal gender differences both in Group A and B IDDM patients, as it has been observed that insulin raises erythrocyte $\mathrm{Na}^{+} / \mathrm{Li}^{+}$CT $[20,22]$. In fact subcutaneous insulin treatment results in chronic peripheral hyperinsulinaemia along with relative under-insulinisation of the portal vein in IDDM patients [30]. It has to be pointed out that the daily insulin requirement was not significantly different in Group A and in Group B, who were followed blindly in outpatient clinics with regard to their erythrocyte $\mathrm{Na}^{+} / \mathrm{Li}^{+}$CT values.

In summary, three different hypotheses can be postulated to explain the link between elevated erythrocyte $\mathrm{Na}^{+} / \mathrm{Li}^{+} \mathrm{CT}$ and the development of renal damage in IDDM. First, the activity of this cation transport system could directly underscore a predisposition to the occurrence of complications at kidney level. Second, erythrocyte $\mathrm{Na}^{+} / \mathrm{Li}^{+}$CT could be the characteristic of IDDM patients resistant to insulin action and thus exhibiting a worse metabolic control. Chronic hyperglycaemia in turn may be responsible for kidney damage. Third, erythrocyte $\mathrm{Na}^{+} / \mathrm{Li}^{+} \mathrm{CT}$ is a marker of predisposition to arterial hypertension. According to this latter view slightly elevated blood pressure levels could play a predominant role in the pathogenesis of diabetic complications at the kidney level.

Whatever the nature of the mechanisms underlying the association between elevated erythrocyte $\mathrm{Na}^{+} / \mathrm{Li}^{+} \mathrm{CT}$ and diabetic nephropathy, the results of the present study seem to provide some new insights. Previous cross-sectional reports [3-5] showed a link between disorders in this cation erythrocyte transport system and incipient or overt nephropathy. This association, however, has not been confirmed by other studies [6]. The present, prospective study shows that IDDM patients with erythrocyte $\mathrm{Na}^{+} / \mathrm{Li}^{+} \mathrm{CT}$ above the median value are more at risk for developing persistent microalbuminuria. Since persistent microalbuminuria precedes the development of overt nephropathy in IDDM, it might be useful to evaluate erythrocyte $\mathrm{Na}^{+} / \mathrm{Li}^{+} \mathrm{CT}$ in normotensive, normoalbuminuric IDDM patients. This could permit early identification of patients at risk of developing renal complications and thus becoming candidates for antihypertensive and intensive insulin treatment and meticulous metabolic control.

Acknowledgements. This work was supported by Grants 910048, 9200345, 9300428, 9400464.PF40 for the Consiglio Nazionale delle Ricerche, Clinical Research Project on Aging.

\section{References}

1. The Diabetes Control and Complications Trial Research Group (1993) The effect of intensive treatment of diabetes on the development and progression of long-term complications in insulin-dependent diabetes mellitus. N Engl J Med 329: 977-986

2. Krolewski AS, Laffel LMB, Krolewski M, Quinn M, Warram JH (1995) Glycated haemoglobin and risk of microalbuminuria in patients with insulin dependent diabetes mellitus. N Engl J Med 332: 1251-1255

3. Krolewski A, Canessa M, Warram J et al. (1988) Predisposition to hypertension and susceptibility to renal disease in insulin dependent diabetes. N Engl J Med 318: 140-145

4. Barzilay J, Warram JH, Bak M, Laffel L, Canessa M, Krolewski A (1992) Predisposition to hypertension: risk factor for nephropathy and hypertension in IDDM. Kidney Int 41: 723-730

5. Mangili R, Bending J, Scott G et al. (1988) Increased sodium lithium countertransport activity in red blood cells of patients with insulin dependent diabetes and nephropathy. N Engl J Med 318: 146-150

6. Jensen J, Mathiesen E, Norgaard K et al. (1990) Increased blood pressure and sodium-lithium countertransport are not inherited in diabetic nephropathy. Diabetologia 33: 19-24

7. The Fifth Report of the Joint National Committee on Detection, Evaluation and Treatment of high blood pressure. (1990) Arch Int Med 153: 154-183

8. Canessa M, Adragna N, Solomon HS et al. (1980) Increased sodium lithium countertransport in red cells of patients with essential hypertension. N Engl J Med 310: 772776

9. Nosadini R, Semplicini A, Fioretto P et al. (1991) Sodiumlithium countertransport and cardiorenal abnormalities in essential hypertension. Hypertension 18: 191-198

10. Griner PF, Mayewsky RJ, Mushlin AI, Greenland P (1981) Selection and interpretation of diagnostic tests and procedures. Ann Intern Med 94 (Part 2) 553-600

11. Dunn PJ, Cole RA, Soeldner JS (1979) Further development and automation of a high pressure liquid chromatographic method for the determination of $\mathrm{HbA}_{1 \mathrm{c}}$. Metabolism 28: 777-779

12. Care RN, Feldbruegger D, Westgard J (1974) Evaluation of the adaptation of the glucose peroxide 3-methyl-2 benzothiazolinone hydrazone-N-N dimethyline procedure to the technicon "SMA" 12/60 and comparison with other automated methods of glucose. Clin Chem 20: 595-602

13. Keen H, Chlouverakis C (1963) An immunoassay method for urinary albumin at low concentrations. Lancet ii:913914

14. Rothman KJ (1986) Modern epidemiology. Boston, Little, Brown and Company, pp 35-114

15. Microalbuminuria Collaborative Study Group, UK (1993) Risk factors for development of microalbuminuria in insulin-dependent diabetic patients: a cohort study. BMJ 306: 1235-1239

16. Mahnensmith RL, Aronson PS (1985) The plasma membrane sodium-hydrogen exchanger and its role in physiological and pathophysiological processes. Circ Res 56: 773-788

17. Rutherford PA, Pizzonia J, Biemesderfer D et al. (1994) Expression of sodium/hydrogen exchange isoforms in the erythrocyte. J Am Soc Nephrol 5: 550

18. Walker JD, Tariq T, Viberti GC (1990) Sodium-lithium countertransport activity in red cells of patients with insulin 
C.G. Monciotti et al.: High erythrocyte $\mathrm{Na}^{+} / \mathrm{Li}^{+} \mathrm{CT}$ and microalbuminuria in IDDM

661

dependent diabetes and nephropathy and their parents. BMJ 301: 635-638

19. Zerbini G, Ceolotto G, Gaboury C et al. (1995) Sodiumlithium countertransport has low affinity for sodium in thyperinsulinemic hypertensive subjects. Hypertension 25: 986-993

20. Rutherford PA, Thomas TH, Wilkinson R (1990) Increased erythrocyte sodium-lithium countertransport activity in essential hypertension is due to an increased affinity for extracellular sodium. Chin Sci 79: 365-369

21. Rutherford PA, Thomas TH, Carr SJ, Taylor R, Wilkinson R (1992) Changes in erythrocyte sodium-lithium countertransport kinetics in diabetic nephropathy. Olin Sci 82(3):301-307

22. Semplicini A (1993) The $\mathrm{Na}^{+} / \mathrm{Li}^{+}$countertransport in hypertension In: Coca A, Gray RP (eds) Ionic transport in hypertension. CRC Press, Bock Raton, Florida, pp 90117

23. Rebbeck TR, Turner ST, Sing CF (1993) Sodium-lithium countertransport genotype and the probability of hypertension in adults. Hypertension. 22(4):560-568

24. Cirillo M, Laurenzi M, Panarelli W et al. (1996) Sodiumlithium countertransport and blood pressure change over time. The Gubbio study. Hypertension 27: 1305-1311
25. Trevisan R, Nosadini R, Fioretto P et al. (1992) Clustering of risk factors in hypertensive insulin-dependent diabetics with high sodium-lithium countertransport. Kidney Int 41: $855-861$

26. Lopes De Faria JB, Jones SL, McDonald F et al. (1992) Insulin resistance and sodium-lithium countertransport activeity in normoalbuminuric insulin-dependent diabetic patients. Diabetes 41: 610-615

27. Nosadini R, Cipollina MR, Solini A et al. (1992) Close relationship between microalbuminuria and insulin resistance in essential hypertension and non-insulin-dependent diabetex mellitus. J Am Soc Nephrol 3:S56-S63

28. Doria A, Fioretto P, Avogaro A et al. (1991) Insulin resisrance is associated with high sodium-lithium countertransport in essential hypertension. Am J Physiol 261:E684E691

29. The Diabetes Control and Complications Trial Research Group (1996) The absence of a glycaemic threshold for the development of long-term complications: the perspectine of the DCCT. Diabetes 45: 1289-1298

30. Nosadini R, Ny A, Natrass M et al. (1982) The metabolic and hormonal response to acute normoglycaemia in type 1 diabetes: studies with a glucose controlled insulin infusion system. Diabetologia 23: 220-228 